\title{
Population Dynamics of Insect Pests and its Natural Enemieson Grain Amaranthin Relation with Weather Parameters
}

\author{
Anil $^{1^{*}}$, Prabhu Ganiger ${ }^{2}$ and Srinivas Reddy ${ }^{2}$ \\ ${ }^{1}$ Department of Entomology, ICAR-Indian Agricultural Research Institute (IARI), \\ New Delhi, India \\ ${ }^{2}$ University of Agriculture Sciences, GKVK, Bangalore, India \\ *Corresponding author
}

\section{A B S T R A C T}

\begin{tabular}{|l|}
\hline K e y w o r d s \\
$\begin{array}{l}\text { Insect pests, Natural } \\
\text { enemies, Weather } \\
\text { parameters and } \\
\text { Grain amaranth }\end{array}$ \\
\hline Article Info \\
\hline $\begin{array}{l}\text { Accepted: } \\
\text { 15 July 2020 } \\
\text { Available Online: } \\
\text { 10 August } 2020\end{array}$ \\
\hline
\end{tabular}

\section{Introduction}

One of the greatest limiting factors in increasing the productivity of leaf amaranth is the damage caused by wide range of insect pests in general, whereas defoliators can cause economic loss (Akinolosotu, 1977). Aderolu et al., (2013) reported 60 insect species associated with amaranthus crop. Hymenia recurvalis caused 8.8 per cent infestation, however, H.recurvalis and Psarabasalis were also common. Agarwal (1985) reported Hypolixus sp., is a major pest in cultivated amaranth. Leaf miner, Liriomyza sp. (Sorensen, 1995), aphid, Myzus persicae are major pest of amaranthus causing leaves

\begin{abstract}
Investigation on incidence of insect pests on grain amaranth was undertaken at MRS, Hebbal, Bengaluru. During study period, 19 insect pests have been recorded throughout the cropping period. Among these, Stem weevil, leaf webber, leaf eating caterpillar and pests are the major one. Five natural enemies were recorded during the present sexmaculata, Cheilomenes vicina (Muls) and Propylea sp. (Coleoptera: Coccinellidae) were found to be feed on aphids, Black bug, Geocoris sp., Assassin bug, Irantha sp. were attacking on Spodoptera sp. and braconid parasitoid, Bracon sp. (Hymenotera :Braconidae) on leaf webber were recorded. Stem weevil population per plant was negatively correlated with maximum temperature and positively correlated with other weather parameters. Whereas Leaf webber and Coreid bug was positively correlated with maximum temperature (0.43) and negatively correlated with minimum temperature.
\end{abstract}

to curl and become unattractive for marketing (Picker et al., 2004; Okunlola et al., 2008). Richard (1989) reported that the leaf worms or cutworms Spodoptera sp., attack young seedlings.

Amaranth leaf webber or webworm larvae fold or web amaranth leaves using their silken webs and feed within the leaves. Hymenia recurvalis, Psarabasalis, Herpetograma bipunctalis are major pests of grain amaranth (Batra and Bhattacherjee, 1960; Bhattacherjee et al., 1964 Clarke-Harris et al., 2003; James et al., 2010 and Grovida, 2015). Information on insect pests of grain amaranth with its natural enemies is scanty. The insect pests 
occurring on grain amaranth is not much work carried out in India. Based on this information efforts were made to study was under taken.

\section{Materials and Methods}

\section{Population dynamics of insect pests and} natural enemies occurring on grain amaranth

Insect pests and natural enemies were collected from amaranth crop from MRS, Hebbal, Bengaluru. Slow moving and sedentary insects were collected by hand using the poison bottle. The plants were examined visually for insect pests and specimens were collected in vials containing 70 per cent alcohol (immature and soft bodied insects), labelled and taken to the laboratory. Beating sheets were used to collect camouflaged or hidden insect pests. Flying insects were collected using aerial nets. Insect pests were collected and preserved for identification. Natural enemies were also collected and preserved for identification.

A field experiment was laid out with plot size was $3.0 \times 3.6 \mathrm{~m}$. Incidence of insect pest and natural enemies on grain amaranth were recorded at weekly intervals by randomly selecting five plants and later pest population and natural enemy population was correlated with weather parameters viz., temperature $\left({ }^{\circ} \mathrm{C}\right)$, relative humidity $(\%)$ and rainfall $(\mathrm{mm})$.

The grain amaranth crop was cultivated by following the package of practices recommended by UAS, GKVK, Bengaluru under protected irrigation except plant protection measures.

\section{Results and Discussion}

\section{Incidence of major insect pests of grain amaranth}

The observations on insect pests and their natural enemies were recorded (Table 1 and 2) at weekly interval till harvest of the crop with (Table 3, 4 and 5 with Fig. 1 and 2).

\section{Stem weevil, Hypolixus truncatulus (Fab.) (Coleoptera: Curculionidae)}

The activity of stem weevil was noticed at seedling stage of the crop i.e. last week of September, $201639^{\text {th }}$ Standard Meteorological Week (SMW) and recorded 0.94weevils per plant. The population of stem weevil increased gradually and reached peak (1.17 weevil/plant) during $43^{\text {rd }}$ SMW. Stem weevil population was low ( 0.36 weevil per plant) at grain filling stage

Leaf webber, Hymenia recurvalis (Fab). (Lepidoptera: Crambidae)

The activity of leaf webber was observed at seedling stage of the crop i.e. first week of October, 2016 i.e. $40^{\text {th }}$ SMW and recorded 0.50 caterpillars per plant. Leaf webber population gradually increased and reached the first peak. (1.57 caterpillar per plant) during $44^{\text {th }}$ SMW and the second peak (1.64) was at $46^{\text {th }}$ SMW. Leaf webber population gradually decreased (0.49) towards harvest of the crop

\section{Ash weevil, (Myllocerus discolor and Myllocerus dorsatus) (Coleoptera: Curculionidae)}

The incidence of ash weevil was observed from seedling stage of the crop i.e. last week of September, 2016 (39 ${ }^{\text {th }}$ SMW) and the population was 0.44 weevils per plant. Later population increased to 0.47 per plant during $40^{\text {th }}$ SMW. The population was low $(0.43)$ at $41^{\text {st }}$ SMW and the weevil population was negligible during vegetative stage ranging from 0.10 to 0.17 per plant. The peak population (0.65) was noticed towards harvesting stage on $48^{\text {th }}$ SMW. 
Leaf eating caterpillar, Spodoptera sp. (Lepidoptera: Noctuidae)

The activity of leaf eating caterpillar started from seedling stage of the crop i.e. last week of September, 2016 (39 $9^{\text {th }}$ SMW) and the caterpillar population was 0.10 per plant. The population reached peak ( 0.84 caterpillars per plant) at $43^{\text {rd }}$ SMW i.e. at vegetative stage of the crop. At grain filling stage of crop the population decreased to 0.37 caterpillars per plant at $47^{\text {th }}$ SMW.

Grasshopper, (Neorthacris acuticeps and Gastrimargus sp.) (Orthoptera: Acrididae)

The incidence of grasshoppers were observed from seedling stage of the crop i.e. last week of September, 2016 ( $39^{\text {th }}$ SMW) and recorded 0.24 grasshopper per plant. The population reached peak on $40^{\text {th }}$ SMW with 0.53 grasshoppers per plant at seedling stage. The population was fluctuating from flowering to grain filling stage. The population increased again on $44^{\text {th }}$ SMW (Standard Meteorological Week) and recorded 0.37 grasshoppers per plant and low population $(0.31)$ during $47^{\text {th }}$ SMW.

\section{Ear-head caterpillar, Helicoverpa armigera} (Hub.) (Lepidoptera: Noctuidae)

The incidence of ear head caterpillar was observed from flowering stage of the crop i.e. last week of October, 2016 ( $43^{\text {rd }}$ SMW) and recorded 0.40 caterpillar per plant. The population reached peak 0.47 caterpillars per plant during $44^{\text {th }}$ SMW at grain filling stage. Later on during $47^{\text {th }}$ and $48^{\text {th }}$ SMW the population showed an increasing trend ranging from 0.30-0.49 caterpillar per plant.

Nineteen insect pests have been recorded throughout the cropping period. Hymenia recurvalis Fab. was found feeding on the crop throughout the growing period of amaranth. Similar reports on $H$. recurvalis has been reported by several workers viz., Batra and Bhattacharjee (1960); Aderolu et al., (2013) and Kigali et al., (2013). Tobacco cut worm, Spodoptera litura (F.) was also observed to feed on leaves of amaranth during cropping period from seedling to grain filling stage. Similar reports on this pest were also reported by Aderlou et al., 2013.

Hairy caterpillar, Euproctis sp. was observed and it defoliated the leaves of amaranth. Similar damage by hairy caterpillar Spilosoma obliqua was also reported by Manjula (2014) where larvae scraped the chlorophyll content of the amaranth leaf and later defoliated the plants completely. Two species of grasshoppers, Neorthacris acuticeps and Gastromorpha sp. were recorded on foliage of amaranth. Both nymphs and adults were found feeding on foliage and shoots. $N$. acuticeps was also reported on amaranth by Garcia et al., (2011); Manjula (2014) and Aderlou et al., (2013).

Stem weevil (Hypolixus truncatulus) was noticed on grain amaranth. Both grub and adult caused damage to the crop from seedling to flowering stage of the crop, which confirms the earlier reports of Aderolu et al., (2013). The results of Torres et al., (2011) and Lopez et al., (2011) study revealed that the infestation of weevil was noticed almost during entire cropping period. Weevil population increased gradually as the crop grew but declined at crop maturity stage. The females oviposit in the stems, larvae fed by tunneling through the stem. This pest resulted in significant crop loss especially by foliage damage. The weevil cause considerable damage on leaves and stems of amaranth. 
Table.1 Insect pests recorded on grain amaranth at MRS, Hebbal, Bengaluru

\begin{tabular}{|c|c|c|c|c|}
\hline Sl. No. & $\begin{array}{l}\text { Common } \\
\text { Name }\end{array}$ & Scientific Name & Family & Order \\
\hline 1 & $\begin{array}{l}\text { Ear head } \\
\text { caterpillar }\end{array}$ & Helicoverpa armigera (Hub.) & Noctuidae & Lepidoptera \\
\hline 2 & Leaf webber & Hymenia recurvalis (Fab.) & Crambidae & Lepidoptera \\
\hline 3 & Stem weevil & Hypolixus truncatulus (Fab.) & Curculionidae & Coleoptera \\
\hline 4 & Leaf beetle & Gametis versicolor (Fab.) & Cetonidae & Coleoptera \\
\hline 5 & $\begin{array}{l}\text { Brown } \\
\text { strippedbeetle }\end{array}$ & Clinteria kluge (Hope.) & Scarabaeidae & Coleoptera \\
\hline 6 & Seed bug & Spilostetchus hospes (Fab.) & Lygaeidae & Hemiptera \\
\hline 7 & Green bug & Nezaraviridula & Pentatomidae & Hemiptera \\
\hline 8 & Seed bug & Graptostetchus servus (Fab.) & Lygaeidae & Hemiptera \\
\hline 9 & Amaranth bug & Cletus sp. (Fab.) & Coreidae & Hemiptera \\
\hline 10 & $\begin{array}{l}\text { Horned coreid } \\
\text { bug }\end{array}$ & Cletomorpha sp.(Fab.) & Coreidae & Hemiptera \\
\hline 11 & Mirid bug & Eurystylus sp.(Stal.) & Miridae & Hemiptera \\
\hline 12 & $\begin{array}{l}\text { Yellow winged } \\
\text { grasshopper }\end{array}$ & Gastrimargus sp. & Acrididae & Orthoptera \\
\hline 13 & $\begin{array}{l}\text { Wingless } \\
\text { grasshopper }\end{array}$ & Neorthacris acutipceps (Bol.) & Pyrgomorphidae & Orthoptera \\
\hline 14 & Stink bug & Halyomorphapicus (Fab.) & Pentatomidae & Hemiptera \\
\hline 15 & Seed bug & Nysius species (Dall.) & Lygaeidae & Hemiptera \\
\hline 16 & Ash weevil & Myllocerus discolor(Boh.) & Curculionidae & Coleoptera \\
\hline 17 & $\begin{array}{l}\text { Myllocerus } \\
\text { weevil }\end{array}$ & Myllocerus dorsatus(Fab.) & Curculionidae & Coleoptera \\
\hline 18 & $\begin{array}{l}\text { White spotted } \\
\text { flea beetle }\end{array}$ & Monolepta signata (Oliv.) & Chrysomeliae & Coleoptera \\
\hline 19 & Stink bug & Dolicoris indicus (Mulst.) & Pentatomidae & Hemiptera \\
\hline
\end{tabular}

Table.2 Natural enemies on insect pests of grain amaranth at MRS, Hebbal, Bengaluru

\begin{tabular}{|c|l|l|l|c|}
\hline Sl. No. & \multicolumn{1}{|c|}{ Common Name } & \multicolumn{1}{|c|}{ Scientific Name } & Family & Order \\
\hline $\mathbf{1}$ & Ladybird beetle & $\begin{array}{l}\text { Cheilomenes sexmaculata } \\
\text { Cheilomenes vicina (Muls.) }\end{array}$ & Coccinellidae & Coleoptera \\
\hline $\mathbf{2}$ & $\begin{array}{l}\text { Fourteen spotted } \\
\text { ladybird beetle }\end{array}$ & $\begin{array}{l}\text { Propylea } \text { sp. } \\
\text { Coccinellidae }\end{array}$ & Coleoptera \\
\hline $\mathbf{3}$ & Black bug & Geocoris sp. & Geocoridae & Coleoptera \\
\hline $\mathbf{4}$ & Assassin bug & Irantha sp. & Reduviidae & Hemiptera \\
\hline $\mathbf{5}$ & Braconidparasitoid & Bracon sp. & Braconidae & Hymenoptera \\
\hline
\end{tabular}


Table.3 Incidence of defoliators and ear head caterpillar on grain amaranth at MRS, Hebbal, Bengaluru

\begin{tabular}{|c|c|c|c|c|c|c|c|}
\hline \multirow[b]{2}{*}{$\begin{array}{l}\text { Standard } \\
\text { Met. Week }\end{array}$} & \multirow[b]{2}{*}{$\begin{array}{c}\text { Date of } \\
\text { observation }\end{array}$} & \multicolumn{6}{|c|}{ Number of insect pests per plant } \\
\hline & & $\begin{array}{c}\text { Stem } \\
\text { weevil }\end{array}$ & $\begin{array}{c}\text { Leaf } \\
\text { Webber }\end{array}$ & $\begin{array}{c}\text { Ash } \\
\text { weevil }\end{array}$ & Grasshopper & Spodoptera & $\begin{array}{l}\text { Ear head } \\
\text { caterpillar }\end{array}$ \\
\hline 39 & $28 / 09 / 2016$ & 0.94 & 0.00 & 0.44 & 0.24 & 0.10 & 0.00 \\
\hline 40 & $04 / 10 / 2016$ & 0.94 & 0.50 & 0.47 & 0.53 & 0.14 & 0.17 \\
\hline 41 & $10 / 10 / 2016$ & 0.74 & 0.57 & 0.43 & 0.37 & 0.07 & 0.00 \\
\hline 42 & $16 / 10 / 2016$ & 0.81 & 0.77 & 0.10 & 0.16 & 0.30 & 0.00 \\
\hline 43 & $22 / 10 / 2016$ & 1.17 & 0.71 & 0.20 & 0.30 & 0.84 & 0.40 \\
\hline 44 & $28 / 10 / 2016$ & 0.4 & 1.57 & 0.17 & 0.37 & 0.44 & 0.47 \\
\hline 45 & $03 / 11 / 2016$ & 0.38 & 1.27 & 0.10 & 0.30 & 0.07 & 0.20 \\
\hline 46 & $09 / 11 / 2016$ & 0.37 & 1.64 & 0.10 & 0.27 & 0.13 & 0.20 \\
\hline 47 & $15 / 11 / 2016$ & 0.57 & 1.29 & 0.14 & 0.31 & 0.37 & 0.32 \\
\hline 48 & $20 / 11 / 2016$ & 0.36 & 0.49 & 0.65 & 0.16 & 0.16 & 0.49 \\
\hline
\end{tabular}

Table.4 Incidence of sucking pests on grain amaranth at MRS, Hebbal, Bengaluru

\begin{tabular}{|c|c|c|c|c|c|}
\hline \multirow{2}{*}{ SMW* } & Date of & \multicolumn{4}{|c|}{ Mean number of insect pests per plant } \\
\hline & observation & Aphids/6leaves/plant. & Horned Coreid bug & Coreid bug & Green bean bug \\
\hline $\mathbf{3 9}$ & $28 / 09 / 2016$ & 0.00 & 1.83 & 1.22 & 0.16 \\
\hline $\mathbf{4 0}$ & $04 / 10 / 2016$ & 0.00 & 1.50 & 1.00 & 0.15 \\
\hline $\mathbf{4 1}$ & $10 / 10 / 2016$ & 0.02 & 1.91 & 1.27 & 0.02 \\
\hline $\mathbf{4 2}$ & $16 / 10 / 2016$ & 0.00 & 1.34 & 0.89 & 0.02 \\
\hline $\mathbf{4 3}$ & $22 / 10 / 2016$ & 0.02 & 1.51 & 1.00 & 0.18 \\
\hline $\mathbf{4 4}$ & $28 / 10 / 2016$ & 0.02 & 2.04 & 1.36 & 0.27 \\
\hline $\mathbf{4 5}$ & $03 / 11 / 2016$ & 0.07 & 1.63 & 1.09 & 0.05 \\
\hline $\mathbf{4 6}$ & $09 / 11 / 2016$ & 0.00 & 2.10 & 1.38 & 0.00 \\
\hline $\mathbf{4 7}$ & $15 / 11 / 2016$ & 0.00 & 1.82 & 2.04 & 0.02 \\
\hline $\mathbf{4 8}$ & $20 / 11 / 2016$ & 0.04 & 4.08 & 1.38 & 0.00 \\
\hline
\end{tabular}

* Standard Meteorological Week

Table.5 Incidence of natural enemies on insect pests of grain amaranth at MRS, Hebbal, Bengaluru

\begin{tabular}{|c|c|c|c|}
\hline SMW* & Date of observation & Mean no. of lady bird beetle & Parasitization (\%) \\
\hline $\mathbf{3 9}$ & $28 / 09 / 2016$ & 0.17 & 0.03 \\
\hline $\mathbf{4 0}$ & $04 / 10 / 2016$ & 0.17 & 0.04 \\
\hline $\mathbf{4 1}$ & $10 / 10 / 2016$ & 0.13 & 0.00 \\
\hline $\mathbf{4 2}$ & $16 / 10 / 2016$ & 0.00 & 0.00 \\
\hline $\mathbf{4 3}$ & $22 / 10 / 2016$ & 0.03 & 0.00 \\
\hline $\mathbf{4 4}$ & $28 / 10 / 2016$ & 0.20 & 0.00 \\
\hline $\mathbf{4 5}$ & $03 / 11 / 2016$ & 0.07 & 0.00 \\
\hline $\mathbf{4 6}$ & $09 / 11 / 2016$ & 0.00 & 0.00 \\
\hline $\mathbf{4 7}$ & $15 / 11 / 2016$ & 0.04 & 0.00 \\
\hline $\mathbf{4 8}$ & $20 / 11 / 2016$ & 0.40 & 0.00 \\
\hline
\end{tabular}

* Standard Meteorological Week 
Table.6 Correlation of major insect pests of grain amaranth with weather parameters

\begin{tabular}{|l|c|c|c|c|c|}
\hline \multicolumn{1}{|c|}{ Insect pests } & \multicolumn{2}{|c|}{ Temperature (\%) } & \multicolumn{2}{c|}{ RH (\%) } & RF \\
\cline { 2 - 6 } & Max. & Min. & Morning & Afternoon & (mm) \\
\hline Stem weevil & -0.42 & 0.50 & 0.34 & 0.53 & 0.25 \\
\hline Leaf webber & 0.43 & -0.14 & $-0.64^{*}$ & -0.38 & -0.49 \\
\hline Earhead caterpillar & 0.59 & -0.62 & -0.59 & $-0.71^{*}$ & -0.60 \\
\hline Ash weevil & -0.34 & -0.13 & $0.63^{*}$ & 0.23 & 0.40 \\
\hline Leaf eating caterpillar & 0.20 & -0.09 & -0.57 & -0.20 & -0.38 \\
\hline Coried bug & 0.42 & $-0.68^{*}$ & -0.35 & -0.60 & -0.07 \\
\hline Horned coreid bug & -0.33 & 0.31 & -0.04 & 0.28 & -0.13 \\
\hline
\end{tabular}

* Significant at 0.05 levels

Fig.1 Incidence of defoliator pests on grain amaranth

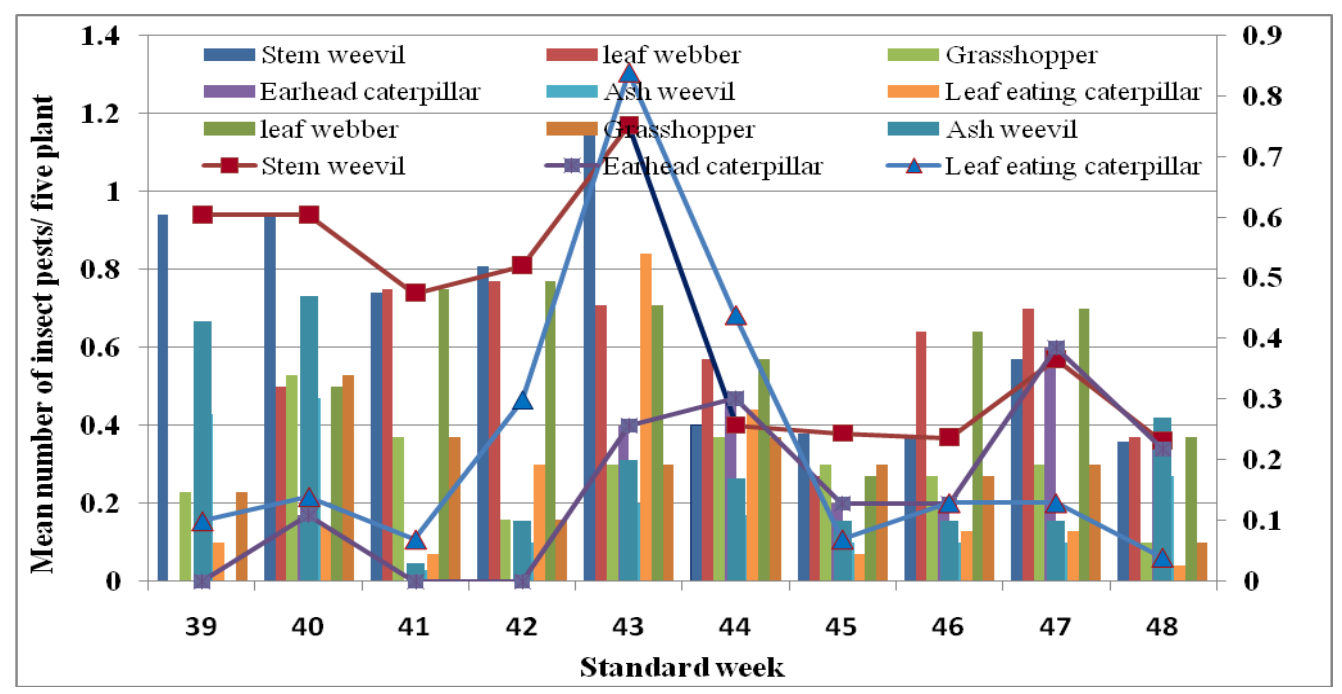

Fig.2 Incidence of sucking pests on grain amaranth

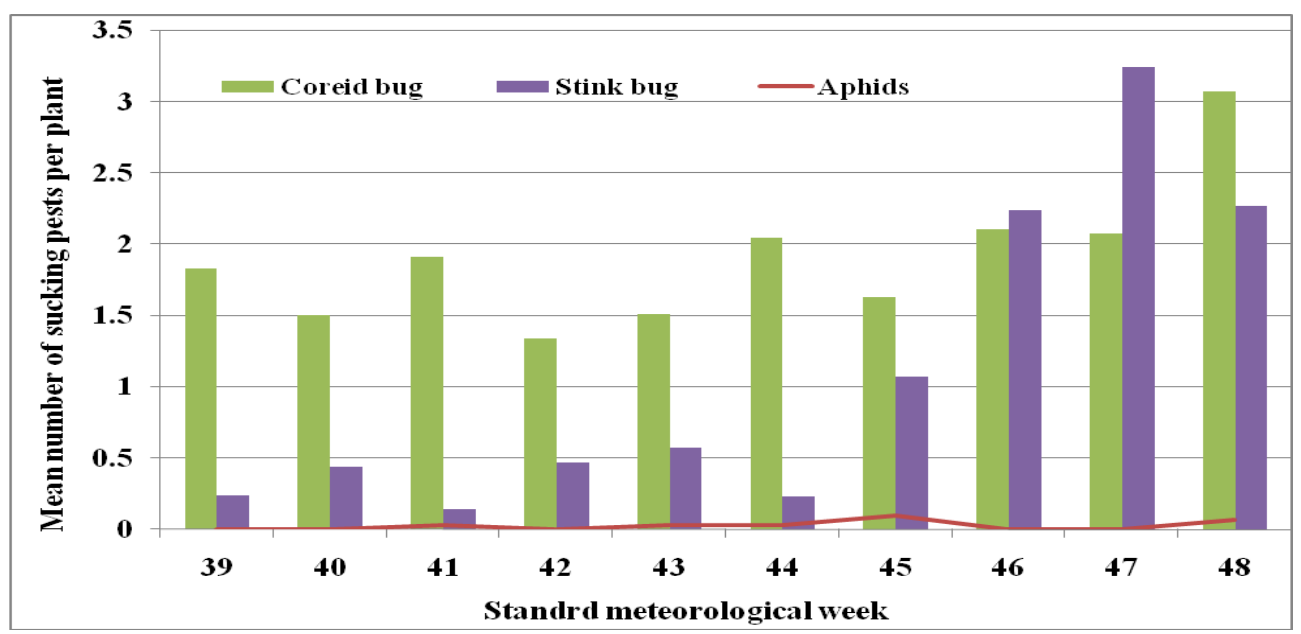




\section{Sucking pests on grain amaranth}

Aphids, Aphis sp. (Hemiptera: Aphididae): The incidence of aphid started from mid of the seedling stage of the crop i.e. second week of October, $201641^{\text {st }}$ (SMW) and recorded 0.02 aphids per plant. The population of aphids reached peak 0.07 aphids per plant at $45^{\text {th }}$ SMW at grain filling stage. The population was negligible (0.04) at harvest stage of the crop (Table 4).

Horned coreid bug, Cletomorpha sp. (Hemiptera: Coreidae)

The incidence of horned coreid bug commenced from seedling stage of the crop at $39^{\text {th }} \mathrm{SMW}$ and recorded 1.83 bugs per plant. The bugs were noticed throughout the cropping period. First peak of 1.91 bugs per plant was recorded during $41^{\text {st }}$ SMW, second peak of 2.04 bugs per plant was observed during $44^{\text {th }}$ SMW and last peak (2.1 bugs per plant) was recorded during $46^{\text {th }}$ SMW. The bug population was at most peaks (4.08) at the end of harvest stage of the crop (Table 4).

\section{Coreid bug, (Cletus sp.) (Hemiptera: Coreidae)}

The activity of coreid bug was observed at seedling stage of the crop i.e. at $39^{\text {th }}$ SMW and recorded 1.22 bugs per plant. The population reached its first peak (1.27) at $41^{\text {st }}$ SMW and second peak 1.36 bugs per plant was recorded at 44th SMW. Further an increasing trend of bugs was noticed during grain filling stage and reached its at most peak (2.04 bugs/plant) at $47^{\text {th }}$ SMW (Standard Meteorological Week) (Table 4).

\section{Green bean bug, (Nezaravi ridula) (Hemiptera: Pentatomidae)}

The activity of green bean bug was observed at seedling stage of the crop i.e. last week of
September, 2016 (39 $9^{\text {th }}$ SMW) and recorded 0.16 bug per plant. The population decreased during two subsequent weeks i.e. 0.02 bugs per plant during $41^{\text {st }}$ and $42^{\text {nd }}$ SMW, respectively. Later the population of bugs reached peak 0.27 bugs per plant at $44^{\text {th }} \mathrm{SMW}$ and thereafter showed a decreasing trend towards grain filling stage of the crop (Table 4)

Aphid, Aphis sp. was noticed on grain amaranth. Both nymphs and adults were found to suck the sap and cause yellowing and drying of leaves. They were found in congregation on under surface of leaves and succulent stems, which conforms the earlier reports of Srivastava and Butani (2009). Pentatomid bug, Nezaravi ridula L. a green coloured bug was observed during the present investigation and found to suck the sap from the tender grains. Similar report of the pest was also reported by Garcia et al., (2011) and Manjula (2014). Coreid bug was noticed on grain amaranth from seedling stage to crop maturity stage. It was found to suck the juice from the grains, causing shrinking and shriveling of grains. These findings are in line with the results of Oke and Ofuya (2011) on population dynamics of Cletus sp. on amaranth in Nigeria and its infestation started at milky stage and continued to accumulate as the crop growth advanced.

\section{Natural enemies on insect pests of grain amaranth}

Five natural enemies were recorded during the present investigation. Two species of predatory ladybird beetle were found to be feed on aphids. Mirid bug and reduviid bug were attacking Spodoptera sp. and Bracon sp. parasitoid on leaf webber. The results are in line with studies of Manjula (2014) who recorded four species of lady bird beetles predators on various pests of amaranth. 
Lady bird beetle, Cheilomenes sexmaculata (Coleoptera: Coccinellidae)

The population of coccinellid grub was 0.17 grubs/ plant at $39^{\text {th }} \mathrm{SMW}$. Later population of grubs decreased gradually at $44^{\text {th }} \mathrm{SMW}$ and recorded 0.20 grubs/ plant. Subsequently the population of grub was increased suddenly during $48^{\text {th }}$ SMW with 0.4 beetles per plant (Table 5).

\section{Braconidparasitoid, Bracon (Hymenoptera: Braconidae)}

sp.

The activity of braconid was observed from $39^{\text {th }}$ SMW to $40^{\text {th }}$ SMW and recorded 0.04 wasp /plant (Table 5).

\section{Correlation of insect pests of grain amaranth with weather parameters}

The average number of stem weevils per plant showed negative correlation with maximum temperature (-0.42), and positive correlation with remaining weather parameters. The number of leaf webber's per plant showed positive correlation with maximum temperature (0.43), and was negatively correlated with remaining weather parameters viz. minimum temperature (-0.14), highly significant negative correlation with morning relative humidity $(-0.64)$ and negatively correlated with afternoon relative humidity (0.38 ) and negatively correlated with rainfall. The number of ash weevil per plant showed negative correlation with maximum $(-0.34)$ and minimum (-0.13) temperature and positive correlation with remaining weather parameters (Table 6).

Incidence of leaf eating caterpillar also showed positive correlation with maximum temperature $(0.20)$ and negative correlation with remaining weather parameters. Incidence of coreid bug showed significantly negative correlation with minimum temperature $(-0.68)$ and positive correlation with maximum temperature (0.42) (Table 6).

\section{Acknowledgement}

Authors would like to thank Dr. C. A. Viraktamath, Former emeritus professor and Principal investigator, Network Project on Biosystematics, Department of Entomology, Gandhi KrishiVignana Kendra (GKVK), Bengaluru for identifying the insect specimens.

\section{References}

Aderolu. I. A. I., Omooloye A. A. and Okelana F. A., 2013. Occurrence, abundance and control of the major insect pests associated with amaranths in Ibadan, Nigeria. Entomol. Ornithol. Herpetol., 2: 5-9.

Agarwal, B. D., 1985, Biology of Hypolixus truncatulus (F). (Coleoptera: Curculionidae) forming galls on the stem of Amaranthus spinosus Lim. in India. Cecidologia Int., 6 (1-3): 83 -90.

Akinolosotu, T. A., 1977. A checklist of insects associated with local vegetables in South west Nigeria. Res. Bulletin, IAR and T. Ife., 5:18-23.

Batra, H. A. and Bhattacherjee, N. S., 1960, Occurrence of Hymenia recurvalis (Fabricius) (Lepidoptera: Pyalidae) as a bad pest on some leaf vegetables. Indian J. Entomol., 22: 128-130.

Bhattacherjee, N. S. andMenon, R. M. G., 1964. Bionomics, biology and control of Hymenia recurvalis (Fabricius) (Lepidoptera: Pyralidae). Indian J. Entomol., 26 (2): 176-183.

Clarke-Harris, D. and Fleischer S. J., 2003, Sequential sampling and biorational chemistries for management of lepidopteran pests of vegetable amaranth in the Caribbean. J. Econ. Entomol., 96: 798-804. 
Garcia, A. A., Huato, D. M. A., Lara, H. M., Cabezon, S. F. J., Morino, I. V. and Olguln, L. J. F., 2011, Insect occurrence and losses due to phytophagous species in the amaranthus, Amaranthus hypocondricius L. crop in Pubea, Mexico. African Journal of Agricultural Research., 6 (27): 59245929.

Grovida, F., 2015.Vegetable pests. http://www.grovida.us/vegetablepests.h tml. Accessed on 26/5/2015.

James, B., Ahowe, A. C., Godonou, I., Baimey, H. and Georgen, H., 2010. Integrated pest management in vegetable production: A guide for extension workers in West Africa. International Institute of Tropical Agriculture (IITA), Ibadan, Nigeria. pp. 120.

Kigali, R. N., Kioko, E. N., Osiemo, Z., Muya, S. and Catherine, W., 2013. Insect abundance and diversity on cultivated Amaranthus (Amaranthaceae) in Meru County Kenya.

Lopez-Olguin, J. F., Garcia, A. A. andHuato, M. A., 2011. Insect occurrence and losses due to phytophagous species in the amaranth (Amaranthus hypocondriacus L.) in Puebla, Mexico. African J. Agric. Res.6 (27), 5924 5929.

Manjula, K. N., 2014. Studies on insect defoliators of amaranthus, fenugreek and palak., M.Sc. Thesis submitted to Univ. of Horticultural Sciences, Bengaluru, Karnataka. Pp. 155.

Oke, O. A. and Ofuya, T. I., 2011. Relationship between population of Cletus fuscescens (Walker) (Hemiptera: Coreidae); Planting dates, Lines and Grain Amaranth (Amaranthus spp.) Phenology. J. Entomol. 8: 566-573.

Okunlola, A. I., Ofuya, T. I. and Aladesanwa, R. D., 2008. Efficacy of plant extracts on major insect pests of selected leaf vegetables in South Western Nigeria. Agric. J. 3: 181-184.

Picker, M., Griffiths, C. and Weaving, A., 2004. Field guide to insects of South Africa. South Africa: Struik Publishers.

Richard, R.W., 1989. Studies of insects feeding on grain Amaranth in the MidWest. J. Kansas Entomol. Soc. 62(4): 440-448.

Sorensen K. A., 1995. Insect pest of Vegetables. North Carolina Agricultural Extension Service. pp. 404.

Srivastava, K. P. and Butani, D. K., 2009.Pest management in Vegetables Vol-1- 2nd edition.p. 381.

Torres P. C. B., Garcia A. A., Aviles R. P., Hernandez L. R. andOlguin J. F. L., 2011. Entomofaunastic study of the cultivation of Amaranth (Amaranthus hypochondriacus L.) in Puebla, Mexico, Revesta Mexicana de Ciencias agricolas. 2(3): 359-371.

\section{How to cite this article:}

Anil, Prabhu Ganiger and Srinivas Reddy. 2020. Population Dynamics of Insect Pests and its Natural Enemieson Grain Amaranthin Relation with Weather Parameters. Int.J.Curr.Microbiol.App.Sci. 9(08): 1414-1422. doi: https://doi.org/10.20546/ijcmas.2020.908.162 